\title{
SOSIALISASI ASPEK MANAJEMEN DAN EKONOMI DI PANTAI LHOK BUBON KECAMATAN SAMATIGA KABUPATEN ACEH BARAT
}

\section{THE SOCIALIZATION OF MANAGEMENT AND ECONOMICAL ASPECT AT LHOK BUBON BEACH SAMATIGA DISTRICT WEST ACEH REGENCY}

\author{
Zuriat $^{1}$ \\ ${ }^{1}$ Prodi Perikanan Fakultas Perikanan dan IImu Kelautan Universitas Teuku Umar \\ Korespondensi: utuzuriat@gmail.com
}

\begin{abstract}
ABSTRAK
Wilayah pesisir merupakan kawasan pemukiman nelayan dan tempat mendaratkan ikan hasil tangkapan, sebagai sebuah aktifitas kehidupan ekonomi. Desa Lhok Bubon merupakan desa nelayan dan tempat wisata bagi masyarakat Kabupaten Aceh Barat. Wilayah pesisir yang berhadapan dengan laut lepas memiliki sebuah pemandangan yang indah dengan pantai yang landai dan ombaknya yang tenang. Desa ini memiliki banyak wisatawan lokal sehingga perlu ditingkatkan dengan usaha bisnis berupa rumah makan dan pelayanan wisata lainnya. Kegiatan pengabdian dilakukan untuk memberikan kesadaran kepada masyarakat dari aspek manajemen dan kegiatan ekonomi produktif, dimana kebutuhan akan wisata merupakan kebutuhan sekunder. Adanya berbagai fasilitas dan menjaga kebersihan pantai. Hal ini akan berpeluang untuk dijadikan wahana wisata prioritas bagi masyarakat sebagai lokasi wisata bahari. Aspek pemberdayaan ekonomi menjadi salah satu materi yang disampaikan untuk meningkatkan motivasi para kaum wanita agar dapat memanfaatkan potensi sumberdaya pesisir sebagai wahana ekonomi keluarga dalam aspek manajemen, seperti perencanaan, organisasi pengelola, pelaksanaan kegiatan pelayanan wisata serta aspek pengawasan dan lokasi wisata islami bagi masyawarat Aceh Barat khususnya dan luar Aceh Barat umumnya
\end{abstract}

Kata Kunci : Pantai, Manajemen, Ekonomi dan Wisata Pantai

\begin{abstract}
Coastal area is fishermen's home area and landed catch fish as an activity of economic life. Lhok Bubon Village is beach subdistrict of fishermen and tourism place for West Aceh community. The coastal area is front of the open oceans have beautiful scene with shallow beach and low wave. This village have a lot of local tourist. Thus, it is necessary to elevate with bussiness such as restaurant and other services. The empowering community was undertaken for giving awareness to local community from management aspect and productive economic activity where the need to tourism are secondary need. With adequate facilities and keep cleanliness of the beach. It have opportunity to be tourism place that priority for local community as marine tourim site. Economical empowerment to be one of material that conveyed to increasing the motivation for women in order to utilize the potency of coastal resources as transport of family economic in management aspect such as plannning, organizing, actuacting of tourism services as well as surveilance aspect and islamic tourism site for West Aceh community especially outside West Aceh.
\end{abstract}

Keywords : Beach, Management, Economical and Beach Tourism 


\section{PENDAHULUAN}

Wilayah pesisir Kabupaten Aceh Barat merupakan suatu kawasan yang sangat strategis ditinjau dari segi teknis, sosial, maupun ekonomi. Hal tersebut dapat dipahami karena selain wilayah pesisirnya memiliki garis pantai sepanjang 56 km, (BPS, 2018). Beberapa lokasi terrdapat areal yang dapat ditumbuhkembangkan sebagai wilayah ekonomi produktif dan rekreasi masyarakat. Dalam dua dekade ini setelah musibah stunami,, laju pemanfaatan pantai Lhok Bubon bagi kepentingan wisata terus mengalami perkembangan pesat. Desa Lhok Bubon merupakan salah satu desa yang ada dalam Kecamatan Samatiga. Secara geografis desa ini berhadapan dengan pantai yang indah dan lautnya yang tenang

Pantai pesisir merupakan kawasan perikanan pantai dengan potensi berbagai aspek yang dapat dikembangkan melalui aktifitas ekonomi dan kemasyarakatan. Desa atau Gampoeng Lhoek Bubon merupakan desa pantai yang telah lama dijadikan sebagai tempat wisata bagi masyarakat Labupaten Aceh Barat. Pesisir pantai yang berhadapan dengan laut lepas merupakan sebuah pemandangan yang menyejukkan mata, sehingga dengan pantainya yang landai dan ombaknya yang tenang menjadikan desa ini banyak dikunjungi oleh banyak orang. Sehingga dapat dikembangkjan jenis usaha beroroientasi bisnis sosial berupa rumah makan ikan bakar dan pelayanan wisata lainnya, fasilitas mandi dan berbagai makanan, serta penjualan hasil kerajinan sebagai pendukung daya tarik wisata.

Kebutuhan akan wisata merupakan kebutuhan umumnya manusia, namun harus disiapkan berbagai fasislitas dan terbebas dari berbagai kotoran, dengan demikian akan terlihat pantai yang indah dan bersih.. Dan peluang ini harus dapat dimanfaatkan oleh masyarakat yang desanya memiliki potensi pesisir pantai untuk dijadikan lokasi wisata bahari.

Didalam masyarakat pesisir pantai menganggap bahwa pantai adalah hanya sebagai sumberdaya alam yang merupakan pinggiran laut, sebagai sumber mata pencaharian untuk aktifitas perikanan dalam arti sumberdaya alam untukmelakukan penangkapan ikan dan kegiatan budidaya ikan. Data BPS (2012), menunjukkan bahwa kecamatan Samatiga memilki potensi sumberdaya laut dengan potensi perikanan tangkap, budidaya dan pengolahan hasil perikanan, yang letak geografisnya berhadapan dengan laut.

Pada aktifitas ekonomi belum dimanfaatkan secara optimal, kalaupun ada hanya digunakan untuk aktifitas rekreasi, hanya sebatas kebutuhan pada hari-hari tertentu saja, belum dimanfaatkan untukmenjadikan sebagai wahana wisata yang diperuntukkan untu umum. Padahan sebagai landasan filosofis potensi pesisir pantai juga dapat dikembangkan menjadi potensi ekonomi dan pemberdayaan aktifitas masyarakat, yang mana potensi didarat dan dilaut harus dimanfaatkan untuk kemakmuran dan kesejahteraan umat, baik untuk generasi sekarang maupun yang akan datang (Tripa, 2012).

Sudrajat et al. (2007), mengemukakan bahwa potensi sumberdaya perikanan mencakup berbagai aspek kegiatan, baik budidaya, penangkapan dan pengolahan hasil perikanan. Hartono (2012) mengemukakan bahwa kegiatan ekonomi yang berlangsung dalam suatu masyarakat memerlukan pemahaman atas berbagai 
perpekstif yang dapat digunakan untuk menerangkan fenomena ekonomi dalam kehidupan masyarakat perikanan.

\section{Rumusan Masalah}

Permasalahan yang diperoleh pada desa pantai adalah belum terurusnya penanganan kebersihan pantai, sehingga banyak sampah terumata plastik yang bertaburan disekitar pantai, dimana masyarakat menggunakan sebagai tempat beristirahat dan berrekreasi. Fenomena ini menjadikan pantai terlihat menjadi kumuh, dan tidak menarik untuk tempat rekkrearasi yang menyenangkan.

Pantai sebagai tempat rekreasi atau wisata, bila kurang nyaman, maka akan membuat pengunjung tidak betah atau tidak belama-lama, padahal melalui kegiatan wisata pantai, dapat menjadi sumber mata pencaharian bagi masyarakat sekitarnya.

Adapun hasil pengamatan dan informasi yang diperoleh ditemui permasalahan sebagai berikut :

1. Kurangnya pengetahuan masyarakat mengenai pemberdayaan pantai sebagai sumber ekonomi.

2. Tidak adanya dorongan dari para pihak agar menjadikan pesisir pantai sebagai fasilitas wisata yang menarik

3. Masih kurang nya fasilitas yang diperlukan bagi pengunjung

4. Masih kurangnya perhatian pihak terkait dalam menjadikan objek wisata yang dapat mendatangkan pengunjung

5. Belum kuatnya kesadaran pentingnya kebersihan pantai

\section{Maksud dan Tujuan}

Adapun maksud dan tujuan dari kegiatan pengabdian masyarakat ini adalah sebagai berikut :

1. Sebagai kewajiban penulis dalam hal Tridarma perguruan tinggi, yang salah satunya adalah pengabdian pada masyarakat

2. Memberikan bimbingan dalam kegiatan pengembangan wisata bahari

3. Bersama kelompok berperan sebagai Pembina kelompok dan bersama-sama membentuk kelompok pengelola pantai

4. Mengembangkan usaha kerajinan yang dapat mendukung objek wisata yang menari dan potensial.

\section{METODE PELAKSANAAN}

Waktu Pelaksanaan

Waktu pelaksanaan kegiatan pembinaan dan Penyluhan ini dibagi dalam beberapa tahapan, dimana pada tahap awal yakni tahap konsolidasi kelompok dan persiapan pelaksanaan kegiatan melalui kegiatan sosialisasi yang dilaksanakan pada tanggal 7 Maret 2019, dengan kegiatan sbb:

a. Pertemuaan kelompok, yang dihadiri umumnya oleh kaum ibu dan mahasiswa, menjadikan acara sosialisasi dan pemberdayaan ekonomi menjadi lebih menarik, dimana para ibu-ibu dengan penuh semangat mendengarkan pemaparan yang disampaikan. dimana tergugah untuk berinovasi melakukan 
yang terbaik, dari sebelumnya menjadi lebih bersih dan indah,dan banyak dikunjungi oleh wisatawan lokal.

b. Lokasi pantai memperlihatkan bahwa aspek kebersihan dan keindahan, sudah ditata dengan adanya tempat duduk permanen yang dibangun pada tahun 2018

c. Temu wicara dan pemaparan materi diarahkanke ekonomi produktif, yang menjadikan desa pantai sebagai wahana wisata menarik dan pantas dikunjungi,telah berjalan dengan baik dan lancar

Metode Pelaksanaan

Metode pelaksanaan pengabdian pada masyarakat ini mengambil metode pembinaan kelompok sebagai berikut :

a. Melakukan pertemuan dengan masyarakat, terutama para usahawan yang telah membuka kios jualan makanan dan minuman.

b. Memberikan wawasan dan pencerahan dengan konsep manajemen pengelolaan pantai.

c. Memberikanan aspek pengembangan ekonomi, yang berorientasi pada pelayanan jasa dan produk pantai

Pelaksanaan Pertemuan

Pelaksanaan pertemuan dalam pembinaan dimaksudkan sebagai upaya mencari solusi dalam pemberdayaan sumberdaya alam dan masyarakat yang bermukim di desa pantai,untuk mewujudkan pantai yang bersih sekaligus dapat dimanfaatkan untukkegiatan wisata dan pemberdayaan ekonomi masyarakat. Adapun solusi yang diberikan dalam upayapeningkatan produkfitas usaha dan pemberdayaan pantai adalah menerapkan konsep manajemen dan sisi ekonomi. Penyampaian materi dilaksanakan dalam bentuk ceramah dan diskusi. Dari sisi manajemen yang perlu dilakukan adalah:

a. Membuat perencanaan usaha

b. Menyusun kelompok usaha skala kecil yang sudah ada

c. Melaksanakan kegiatan usaha dari sisi kepentungan pengunjung

d. Membentuk kelompok pengaman pantai dari unsur pemuda setempat dan tim pengawas pelaksanaan usaha, atau dengan kata lain tim pengendali mutu

\section{HASIL DAN PEMBAHASAN}

\section{Sosialisasi Manajemen Pantai}

Desa Lhok Bubon merupakan salah satu desa dari beberapa desa yang dihampari pantai yang landai, dimana lokasi ini sudah lama menjadi sasaran masyarakat untuk berwisata yaitu masyarakat kabupaten Aceh Barat dan aktifitas ekonomi perikanan, seperti nelayan, pengolah ikan dan budidaya..

Pesisir pantai yang berhadapan dengan laut lepas merupakan sebuah pemandangan yang menyejukkan mata, sehingga dengan pantainya yang landai dan ombaknya yang tenang menjadikan desa ini banyak dikunjungi oleh banyak orang. Sehingga dapat dikembangkan jenis usaha berorientasi bisnis sosial berupa rumah makan ikan bakar dan pelayanan wisata lainnya, fasilitas mandi dan berbagai makanan, serta penjualan hasil kerajinan sebagai pendukung daya tarik wisata. 
Kebutuhan akan wisata merupakan kebutuhan umumnya manusia, namun harus disiapkan berbagai fasilitas dan terbebas dari berbagai kotoran, dengan demikian akan terlihat pantai yang indah dan bersih.. Dan peluang ini harus dapat dimanfaatkan oleh masyarakat yang desanya memiliki potensi pesisir pantai untuk dijadikan lokasi wisata bahari.

Aspek pemberdayaan ekonomi menjadi salah satu materi yang disampaikan,dimanadimaksudkan adalah untuk membuka pikiran dan animo para kaum ibu, agarvdapat memanfaatkan potensi pesisir pantai nya sebagai wahana ekonomi untuk sumber mata pencaharian tambahan. Pendataan terhadap aspek yang akan dikembangkan adalah suatu hal sangat penting bagi pengembangan wisata yang menarik, namun hal tersebut perlu dirumuskandan membuat payung hukum, agar potensi pantai dapat digali sebagai sumber pendapatan bagi desa dan masyarakat dimasa yang akan datang.

Dalam penyampaian ceramah sebagaimana terlihat pada photo (pelaksana pengabdian) bahwa dalam penyampaian materi mendapat sambutan dari peserta yang hadir, yang ditunjukkan tingkat keseriusan dalam mendengar terhadap materi yang disampaikan.

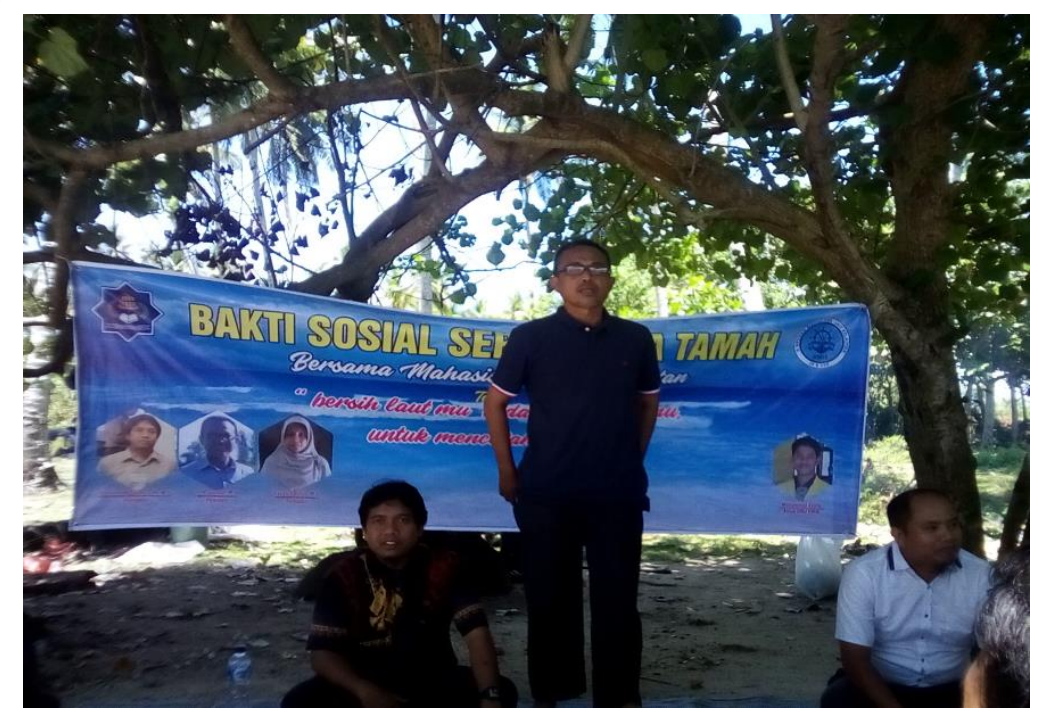

Gambar 1. Penyampaian materi sosialisasi di Pantai Lhok Bubon

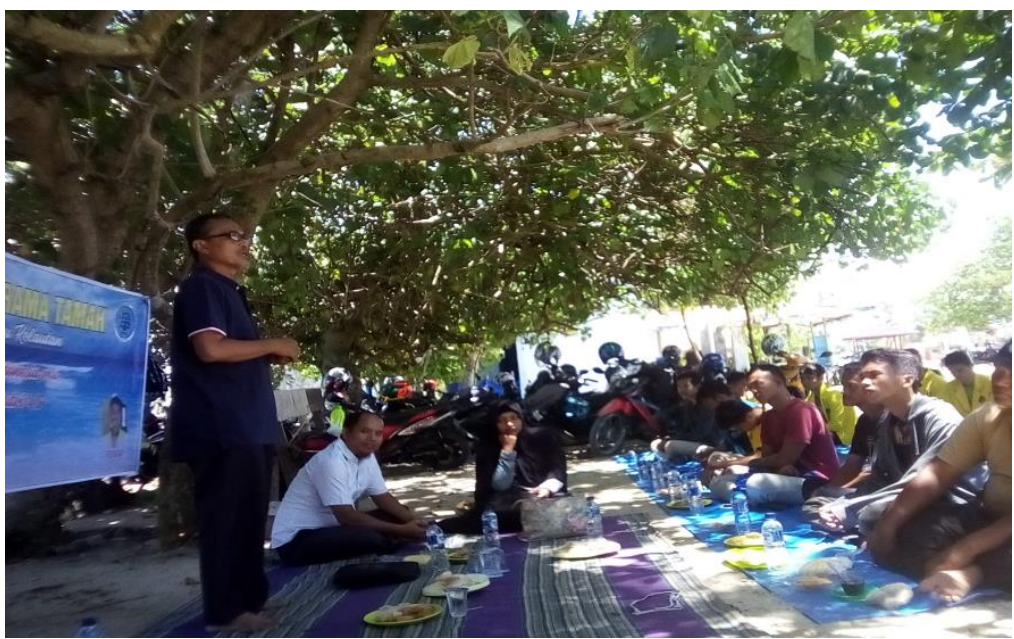

Gambar 2. Melakukan diskusi dan pertanyaan dari para peserta sosialisasi 
Hasil dari pelaksanaan sosialisasi dan pembinaan kepada masyarakat Desa Lhoek Buboen, yang dihadiri oleh kaum ibu-ibu, maka dapat diperoleh hasil sbb:

1. Masyarakat mengharapkan adanya pembinaan yang berkelanjutan, dimana setiap bulannya dibuat program pembersihan pantai

2. Masyarakat, berminat mengelola pantai sebagai wahana wisata bahari, namun terkendala dalam manajemen engelolaannya

3. Diperlukan langkah-langkah tindak lanjut, untuk mempersiapkan secara utuh kesiapan pengelola, payung hukum dan rancangan kebutuhan atau fasilitas penunjang

4. Diperlukan adanya pembinaan terpadu antar instansi yang terkait, seperti pembinaan dalam meningkatkan kerajinan yang bersumber dari tanaman pantai seperti sabut kelapa, daun kepalap dan lidi yang dapat dijadikan alat alat keperluan rumah tangga

5. Masyarakat menyambut baik pemikiran kearah kemajuan, namun perlu didampingi dalam perwujudannya.

\section{Rencana Aksi Kelompok}

Adapun rencana aksi kelompok lebih lanjut adalah mempersiapkan keramba yang dapat menampung ikan karang, udang dan lainnya dalam bentuk masih hidup, sehingga mempunyai nilai daya tarik tersendiri bagi pengunjung. Dimana pantai Lhoek Buboen harus memiliki ciri khas dalam mengembangkan dan menghidupkan wisata lokal.

Program pengembangan keramba ikan laut dipantai yang tenang, perlu dilakukan tindak lanjut dengan berkoordinasi dengan para pihak terkait dalam hal ini instansi pemerintah, baik DKP atau yang membidangi kepariwisataan di tingkat Kabupaten Aceh Barat

\section{Penguatan Kelompok}

Untuk penguatan kelompok, diiperlukan rapat dengan pihak aparatur desa dalam pembentukan kelompok pengelola pantai, dan pelatihan yang diperlukan serta aturan-aturan pelaksanaannya.

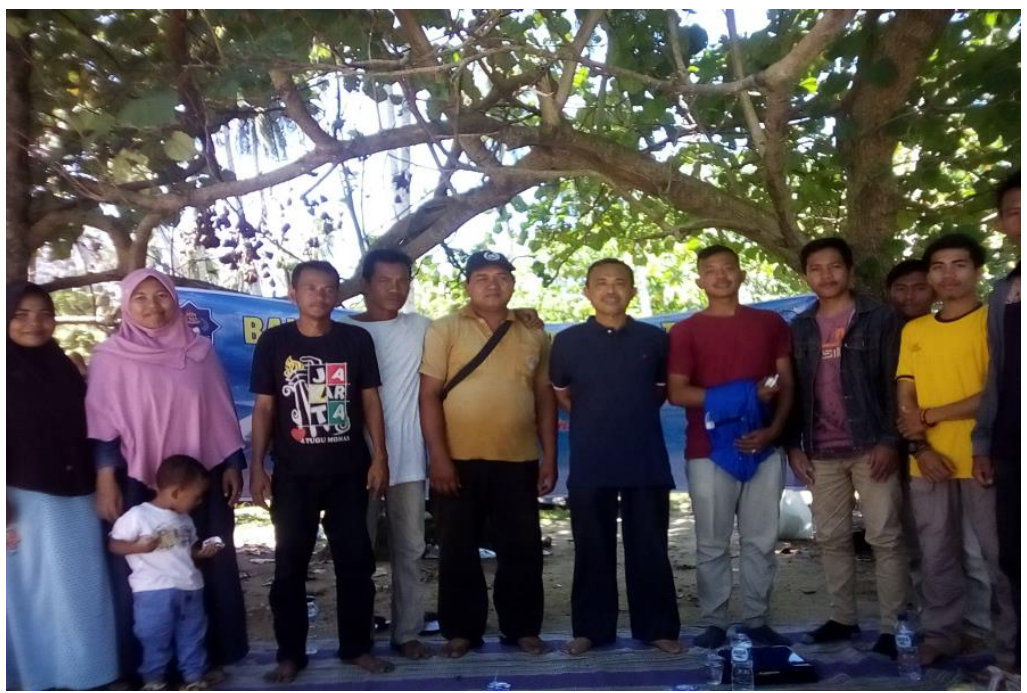

Gambar 4. Foto Bersama Pencinta Pantai Klub 


\section{Penguatan Pengelolaan}

Pelaksanaan kegiatan usaha yang berbasis masyarakat, diperlukan sebuah kekuatan manajemen yang konkrit dan berkesinambungankati hal-hal sbb.

- Diperlukan adalah pengelolaan yang terorganisir

- Setiap anggota masyarakat memerlukan kejelasan, mengenai fungsi pantai sebagai sarana wisata, kaernanya diperlukan pemahaman yang berkesinambungan

- Untuk maksud tersebut, perlu dilakukan pendekatan dengan pihak pemerintah kabupaten dan instansi pembina

Salah satu permasalahan yang dihadapi adalah adanya persoalan kewenangan dalam pengelolaan lokasi, jika dijadikan kawasan wisata dan aktifitas ekonomi. Dimana kewenangan ini terkait dengan berbagai tugas instansi pemerintah. Namun hal ini dapat dilakukan komunikasi dengan pemerintah kabupaten, untuk pelimpahan kewenangan pengelolaan kepada masyarakat desa, pihaqk instansi dapat berperan dalam pembinaan dan pengembangan kepariwisataan dan peningkatan keterampilan dalam kerajinan dan industri kecil yang berbasis pada sumber daya alam dan masyarakat pesisir pantai.

Ditinjau dari aspek manajemen bahwa suatu usaha baik barang maupun jasa akan dapat berkembang dengan baik, maka haruslah didukung oleh aspek penyediaan sarana pelayanan, fasilitas pelayanan, penyediaan kebutuhan pengunjung, lembaga ekonomi dan sosial yang turut serta mendukung aspek pengembangan (Soeleman, 2007).

Untuk itu haruslah dimulai dengan sebuah perencanaan yang faktual, dari mulai perswiapan, pelaksanaan dan pengembangan. Dari aspek pengembangan dirancang sebuah lokasi wisata yang spesial sebagai tempat yang menyenangkan dan memuaskan, melalui penyediaan makanan khas yang dapat dinilmati oleh pengunjung. Untuk menarik pengunjungh dapat dilakukan promosi melalui berbagai media online, sehingga dapat diketahui oleh masyarakat banyak

Rencana tahapan tindak lanjut

1. Penambahan sarana rileks, tempat istirahat santai, bermain, berenang, mainnan anak anak sbg sarana wisata.

2. Penyediaan jasa dan barang bagi pengunjung, makanan khas, sehingga diperlukan

3. Wahana sovenir lokal

4. Lembaga atau kelompok pemberdayaan ekonomi, seperti koperasi KUB

5. melibatkan lembaga eksternal

6. Promosi

\section{Penguatan Lokasi}

Sebagai lokasi yang mempunyai daya tarik,maka harus diperkuat dengan suatu ketentuan atau ketetapan sebagai wilayah yang mempunyai hak untuk difungsikan sebagai pantai wisata bahari yang layak, karenanya diharapkan dibuat sebuah ketentuan yang menjadi dasar pengelolaan sebagai lokasi wisata 


\section{Penguatan Promosi}

Dengan perkembangan usaha pengelolaan pesisir pantai sebagai tempat wisata, maka diperlukan kerja keras dalam memasarkannya melalui promosi yang dimotori oleh pemkab bersama intansi terkait, dan itu dapat dilakukan setelah adanya penetapan organisasi pengeloala dan ketentuan yang menetapkan Pantai Desa Lhok Bubon sebagai lokasi wisata lokal. Untuk perlu dilakukan pembenahan sbb.

\section{a. Manajemen Sumber Daya Perikanan}

Dalam pengelolaan otensi pesisir pantai diperlukan suatu manajemen yang tepat, sehingga tujuan yang ingin dicapai dapat diwujudkan. Manajemen sumber daya perikanan menurut Sondita (2010) adalah suatu manajemen yang mengatur pemanfaatan sumber daya perikanan, dengan rangkaianproses mulai dari pengumpulan data hingga pelaksanaan kebijakan dan tindakan-tindakan manajemen untuk mencapai tujuan yang ditetapkan.

\section{b. Rancangan Pengembangan}

Untuk meujudkan lokasi yang layak dan prospektif, maka perlu bantuan teknis bagi kelompok masyarakat gampoeng dalam bentuk pandangan untuk membuat semacam usulan ke piahk terkait untuk menjadikan pantai pesisir Kuala Buboen sebagai kawasan wisata bahari yang berkemajuan dan produktif, ekonomis, memadai dan bergengsi dengan dilengkapi berbagai kebutuhan wisata. Dan hal ini perlu dilakukan pembicaraan lebih lanjut dengan aparatur Gampoeng dan kecamatan, mengingat lokasi wisata tersebut, umumnya adalah tanah milik masyarakat yang sudah banyak penduduknya dan tanaman perkebunan seperti pohon kelapa, dan lainlain.

\section{KESIMPULAN DAN SARAN Kesimpulan}

Kesimpulan yang dapat di sampaikan dalam laporan ini adalah kampus yang dalam hal ini adalah para dosen, terus menjalin hubungan dengan masyarakat yang semakin terus meningkat, dimana dari hasil pertemuan/sosialisasi masyarakat terlihat begitu bersemangat menyambut kedatangan dosen dan mahasiswa, dan turut mendukung pemikiran pemikiran yang disampaikan, dalam upaya memanfaatkan posisi strategis desa sebagai sarana wisata pantai dan bahari.

\section{Saran}

1. Perlu secara berkala dilakukan pertemuan dan atau pendampingan dengan kelompok masyarakat pantai Desa Lhok Bubon.

2. Perlu dilaksanakan diversifikasi usaha, yang terkait dengan kegiatan wisata seperti aneka kerajinan dan lainnya, serta fasilitas wisata yang memadai baik fasilitas darat, permainan air, berenang dan alat selam.

3. Perlu dibentuk kelompok pengrajin, yang dapat memproduksi hasil kerajinan berbasi dari bahan tanaman pantai dan hasil laut, sebagai upaya peningkatan pendapatan penduduk dan sekaligus sovenir bagi pengunjung pantai. 


\section{Ucapan Terima Kasih}

Penulis mengucapkan terima kasih kepada Keuchick Gampong Lhok Bubon yang telah memfasilitasi kegiatan pengabdian kepada masyarakat. Selain itu, tak lupa pula ucapan terima kasih setinggi-tingginya kepada kelompok ibu-ibu dan peserta yang telah memberikan waktu dan kesempatan dalam melakukan kegiatan pengabdian kepada masyarakat di pantai Gampoeng Lhok Bubon

\section{Daftar Pustaka}

BPS 2012. Kecamatan Samatiga Angka, . Badan Pusat Statistik. Aceh Barat Daya.

Sudrajat et al. (2007). Teknologi Untuk Pemberdayaan Masyarakat Pesisir, Seri Budidaya. Direktorat Pemberdayaan Masyarakat Pesisir, Direktorat Jenderal Kelautan, Pesisir Dan Pulau-Pulau Kecil. Kementerian Kelautan Dan Perikanan. Jakarta

Tripa, S. 2012. Model Kebijakan Pengelolaaan Perikanan, Pusat Studi Hukom Adat Laot, Unsyiah. Banda Aceh. Priyambodo Dan Wahyuningsih, 2004) Budidaya Pakan Alami Untuk Ikan, Penebar Swadaya, Jakarta 